\title{
Innovations in Energy Engineering and Cleaner Production: A Sustainable Chemistry Perspective
}

\author{
Francesca Deganello ${ }^{1, *(1)}$ and Jan-Willem G. Bos ${ }^{2}$ (1) \\ 1 Institute for the Study of Nanostructured Materials (ISMN)-Italian National Research Council (CNR), \\ Via Ugo La Malfa 153, 90146 Palermo, Italy \\ 2 Institute of Chemical Sciences and Centre for Energy Storage and Recovery, School of Engineering and \\ Physical Sciences, Heriot-Watt University, Edinburgh EH14 4AS, UK; j.w.g.bos@hw.ac.uk \\ * Correspondence: francesca.deganello@cnr.it
}

check for updates

Citation: Deganello, F.; Bos, J.-W.G. Innovations in Energy Engineering and Cleaner Production: A

Sustainable Chemistry Perspective.

Sustain. Chem. 2022, 3, 112-113.

https://doi.org/10.3390/

suschem 3010008

Received: 1 March 2022

Accepted: 2 March 2022

Published: 3 March 2022

Publisher's Note: MDPI stays neutral with regard to jurisdictional claims in published maps and institutional affiliations.

Copyright: (C) 2022 by the authors. Licensee MDPI, Basel, Switzerland. This article is an open access article distributed under the terms and conditions of the Creative Commons Attribution (CC BY) license (https:// creativecommons.org/licenses/by/ $4.0 /)$.
This Special Issue is focused on the chemical aspects of sustainable energy engineering and the clean production of materials.

Chemical processes are the foundation of the sustainable production of materials, chemicals, and energy. However, any sustainable approach requires an interdisciplinary vision of science, technology, and economics. A recent paper on the extraction of iron from waste [1] pointed out the importance of a holistic approach, including sustainable chemistry in combination with other disciplines, such as engineering, physics, geology, and economics. Another example of a multidisciplinary approach is the recovery of lignocellulose, where chemical processes are often combined with biological ones for the cleaner production of lactic acid [2].

A good starting point for sustainable production is the "green chemistry" principles. However, a wider perspective needs to be taken into consideration, embracing life cycle assessment concepts and environmental impacts on present and future generations [3]. This holistic approach is important because improvements to individual parts of the process may not lead to better overall outcomes, if other factors, such as environmental or resource considerations, are taken into consideration. Improvements in materials' performance and stability can significantly increase the overall sustainability by extending their working life and hence reducing their footprint in terms of chemical usage and energy costs in production, as fewer components are needed over time [4]. In addition, new sustainable approaches in the laboratory should consider the translation to a larger scale, that is ultimately required to achieve a meaningful impact [5]. Improving the energy efficiency of the industrial production of materials and chemicals can make a great contribution to overall sustainability [6]. Recent interesting examples include the process intensification of photocatalytic processes [7], energy efficient strategies for cleaning industrial wastewater [8], and time/energy-efficient technologies for biodiesel production [9].

Regarding energy engineering, there are two main areas where sustainable chemistry plays an important role. The first is the replacement of fossil fuels with renewable energy sources (e.g., solar fuels). The second is the "electrification" of chemical processes, i.e., integration of renewable energy in the chemical production, and the transition from chemical fuels to electrochemical energy storage, as discussed by Centi et al. [10]. The change from fossil fuels to renewable energies is challenging, and both technologies will coexist for some time [11]. This means there are opportunities for sustainable chemistry in both existing and future energy engineering infrastructure. In particular, for future renewable energy technologies there is an opportunity to embed sustainable approaches from the outset. For example, end-of-life recycling of electrical devices should inform the initial design and the choice of materials and components according to sustainability concepts [12].

To conclude, this Special Issue aims to bring together chemical sustainability innovations in material production and energy engineering. This is not limited to materials 
for sustainable energy but is more generally focused on improvements in clean material production. Here, the energy efficiency of production is important, but so are factors such as lowering the environmental impact and easier end-of-life recycling. The goal of this Special Issue is to have a collection of articles that reflects and helps define the wide variety of contributions that sustainable chemistry can make to clean material production and energy engineering. This includes small-scale lab research but also embedding scale-up and technology transfer in industry. We look forward to your submissions.

Conflicts of Interest: The authors declare no conflict of interest.

\section{References}

1. Tang, Z.; Zhang, Q.; Sun, Y.; Gao, P.; Han, Y. Prospects of green extraction of iron from waste dumped flotation tailings by H2: A pilot case study. J. Clean. Prod. 2022, 330, 129853. [CrossRef]

2. Esquivel-Hernández, D.A.; García-Pérez, J.S.; López-Pacheco, I.Y.; Iqbal, H.M.N.; Parra-Saldívar, R. Resource recovery of lignocellulosic biomass waste into lactic acid-Trends to sustain cleaner production. J. Environ. Manag. 2022, $301,113925$. [CrossRef] [PubMed]

3. Ganesh, K.N.; Zhang, D.; Miller, S.J.; Rossen, K.; Chirik, P.J.; Kozlowski, M.C.; Zimmerman, J.B.; Brooks, B.W.; Savage, P.E.; Allen, D.T. Green Chemistry: A Framework for a Sustainable Future. Organometallics 2021, 40, 1801-1805. [CrossRef]

4. Prézélus, F.; Remigy, J.C.; Guigui, C.; Tiruta-Barna, L. Does substituting reprotoxic solvents during ultrafiltration membrane fabrication really mitigate environmental impacts? Focus on drinking water production. J. Clean. Prod. 2022, 337, 130476. [CrossRef]

5. Galant, O.; Cerfeda, G.; McCalmont, A.S.; James, S.L.; Porcheddu, A.; Delogu, F.; Crawford, D.E.; Colacino, E.; Spatari, S. Mechanochemistry Can Reduce Life Cycle Environmental Impacts of Manufacturing Active Pharmaceutical Ingredients. ACS Sustain. Chem. Eng. 2022, 10, 1430-1439. [CrossRef]

6. Lozano, F.J.; Lozano, R.; Freire, P.; Jiménez-Gonzalez, C.; Sakao, T.; Ortiz, M.G.; Trianni, A.; Carpenter, A.; Viveros, T. New perspectives for green and sustainable chemistry and engineering: Approaches from sustainable resource and energy use, management, and transformation. J. Clean. Prod. 2018, 172, 227-232. [CrossRef]

7. Constantino, D.S.M.; Dias, M.M.; Silva, A.M.T.; Faria, J.L.; Silva, C.G. Intensification strategies for improving the performance of photocatalytic processes: A review. J. Clean. Prod. 2022, 340, 130800. [CrossRef]

8. Jain, A.; Rai, S.; Srinivas, R.; Al-Raoush, R.I. Bioinspired modeling and biogeography-based optimization of electrocoagulation parameters for enhanced heavy metal removal. J. Clean. Prod. 2022, 338, 130622. [CrossRef]

9. Patil, A.D.; Baral, S.S.; Dhanke, P.B.; Dharaskar, S.A. Cleaner production of catalytic thumba methyl ester (Biodiesel) from thumba seed oil (Citrullus colocyntis) using $\mathrm{TiO}_{2}$ nanoparticles under intensified hydrodynamic cavitation. Fuel 2022, $313,123021$. [CrossRef]

10. Centi, G.; Iaquaniello, G.; Perathoner, S. Role of chemical engineering in renewable energy. BMC Chem. Eng. 2019, 1, 5. [CrossRef]

11. Schlögl, R. Sustainable Energy Systems: The Strategic Role of Chemical Energy Conversion. Top. Catal. 2016, 59, 772-786. [CrossRef]

12. Fahimi, A.; Ducoli, S.; Federici, S.; Ye, G.; Mousa, E.; Frontera, P.; Bontempi, E. Evaluation of the sustainability of technologies to recycle spent lithium-ion batteries, based on embodied energy and carbon footprint. J. Clean. Prod. 2022, 338, 130493. [CrossRef] 